\title{
Study on the Development Strategy of Tourist Souvenirs in Changbai Mountain Nature Reserve*
}

\author{
Liguang Zhao \\ School of Taxation \\ Jilin University of Finance and Economics \\ Changchun, China 130117
}

\author{
Mingju Liu \\ Yatai School of Business Management \\ Jilin University of Finance and Economics \\ Changchun, China 130117
}

\author{
Yuqiao Jin \\ Yatai School of Business Management \\ Jilin University of Finance and Economics \\ Changchun, China 130117
}

\begin{abstract}
As an important representative of tourism commodities, the proportion of tourism souvenirs' income in tourism industry shows the degree of development of tourism industry in a country or a region. At present, the sales revenue of tourist souvenirs in Changbai Mountain Nature Reserve is far behind the hot spots. In order to promote the industrialization of tourist souvenirs and promote the rapid development of tourism in Changbai Mountain Nature Reserve, this paper analyzes the current problems in the tourism souvenir market of Changbai Mountain Nature Reserve, and proposes countermeasures for its development based on the existing problems, which will not only greatly promote the development of tourist souvenirs in Changbai Mountain Nature Reserve, but also contribute to development of the entire tourism in Changbai Mountain.
\end{abstract}

Keywords-Changbai Mountain Nature Reserve; tourism; tourist souvenirs; development

\section{INTRODUCTION}

As the tertiary industry of modern society, tourism has become one of the important industries to increase GDP. Changbai Mountain is not only one of China's top ten famous mountains, but also in the eight scenic spots standings in Jilin. At the same time, as an important tourist attraction in Jilin Province, it has rich natural resources and strong cultural heritage, providing unique themes and space for the development of tourist souvenirs. If tourist souvenirs can be developed according to their characteristics, the scenic sports can attract more and more tourists to visit and contribute to the sustainable development of Changbai Mountain.

\section{TOURIST SOUVENIR OVERVIEW}

\section{A. Tourist Souvenir Definition}

Tourist souvenirs not only refer to exquisite craft gifts with regional and national characteristics, but also souvenirs of the

*Fund projects: Jilin Province Social Science Project (2018B81) Jilin Province Department of Education Project (JJKH20170140SK)

National Natural Science Fund of China (Project No. 41401146) soul. They have high collection and appreciation value. The definition of tourist souvenirs in the academic world is still unclear, but from the perspective of attributes, tourist souvenirs are a kind of tourism goods. However, unlike ordinary tourist goods, it can intuitively indicate the characteristics and uniqueness of tourist destinations with value both in collections, art, gifts, etc. and a unique position in the tourism market.

The tourist souvenirs tend to be defined in two types: in a broad sense, as long as it is a tourism memorabilia that carries tourist-related tourism memories, it can be called a tourist souvenir. Based on this sense, even stones and leaves can be called tourist souvenirs. In a narrow sense, a tourist souvenir should first be a commodity. Tourist souvenirs should be purchased by tourists in the course of tourism activities for non-commercial consumption such as personal collections, with local characteristics or special techniques, or goods made from local raw materials. Such as, travel commemorative postcards, printed materials, woven textiles, or local sculptures and sculptures, seals, calligraphy and so on. This kind of tourist souvenirs can not only remind people of the scenery when enjoying souvenirs, but also a microcosm of the characteristic culture and scenery of the tourist place.

\section{B. Tourist Souvenir Features}

1) Culturality: Tourist souvenirs have deep cultural roots in different regions, so culture is the vitality of these souvenirs Tourist souvenirs are the yardstick for the development of social civilization and the standard for measuring folklore, culture, economy and politics in the region. The more vivid the cultural characteristics are, the higher their value is.

2) Commemoration: Commemorativeness is the fundamental element of the existence of tourist souvenirs. Tourism consumers often would like to commemorate the experience in tourism and then generate shopping behavior. The factors that commemorative significance comes into being are multi-faceted. On the one hand, it is influenced by 
the environment of the tourist destination, including being driven by the local people, atmosphere and scenery. On the other hand, it is influenced by the aesthetics, beliefs and experiences in tourism. Tourists in the process of tourism will have feelings for many aspects of the tourist destination, even when they leave, because they can not take away even a brick and tile there, they will be sad. In response, tourist souvenirs rise and they have become the emotional sustenance of tourists by recording the spatial environment, geographical names, and scenic culture that tourists pass through in the process of tourism. Wherever the tourists go, the scenic spots and historic sites, characteristic buildings are concentrated into the souvenirs.

3) Regionalism: The essential characteristic of tourist souvenirs is its regional character. According to the comparison of the natural environment, social culture and economic situation of the tourist's residence and destination, tourist souvenir means a comparative advantage of the region. Tourist souvenirs can represent the natural environment of a tourist area, rich resources, and special food etc. Therefore, the materials and crafts of tourist souvenirs mainly originate from tourist destinations. The display content should have landmark elements and themes, and eventually become a symbol of tourist destinations. The more obvious the regional characteristics of tourist souvenirs are, the more attractive they are to tourists, so they can arouse tourists' desire and behavior to buy, and promote and publicize the local culture.

4) Aesthetics: Beauty at any time has a moving charm, and exquisite beauty is also the basic characteristics of tourism products. Therefore, on the premise of carrying and spreading culture, tourist souvenirs should also pay attention to make use of modern elements and the implant of fashion symbols.

5) Portability: Generally speaking, tourism activities have many characteristics, such as randomness, remoteness and disposability, which to some extent reduce tourists' consumption desire. There are also some cases where tourist souvenirs are too large to be carried in long journey even if the tourists have been impressed. Therefore, from the perspective of liquidity, small and delicate tourist souvenirs which are easy to carry and transport will be more favored.

\section{ADVANTAGES OF DEVELOPING TOURIST SOUVENIRS IN Changbai Mountain Nature RESERVE}

\section{A. Unique Natural Resources}

Changbai Mountain, located on the border between China and Korea, has been China's sacred territory since ancient times. As a famous mountain in China, it is the birthplace of Songhua River, Tumen River and Yalu River, and it is the highest peak in eastern Eurasia. Because its main peak is covered by white pumice and snow, Changbai Mountain is famous for its vast and unique natural resources and cultural accumulation. As the nature reserve with the richest species and the most complete ecosystem preservation in the same latitude of the earth, it has not only primitive forests, tundra, meadows, but also lakes, rivers, swamps and so on. It is a typical representative of the whole Eurasian continent.

Changbai Mountain Tianchi, four vertical landscapes, waterfalls and Lin Hai are selected as the "Guinness" world's top, and enjoy the reputation of one of China's ten famous mountains, one of China's five most beautiful lakes and one of China's ten forests. Changbai Mountain embraces universal value, outstanding natural quality and rich cultural connotation in many aspects such as ecology, biology, geology, history and so on.

\section{B. Mysterious National Customs}

Changbai Mountain has abundant Shaman cultural resources. Many religious relics such as sacrifices, singing and dancing, folk customs and so on are preserved intact. With the development of the times, people pay more and more attention to the cultural characteristics of tourism products. Understanding the local historical background and cultural customs has become one of the motives for modern people to travel. In order to adapt to changes in market demand, new tourism products must be developed to enhance the desire of tourists to purchase. In this context, the types of tourist souvenirs should be increased to stabilize the economic situation of the tourism market, boost the rate of returned visits, and extend the life cycle of local tourist areas. The development and utilization of Shaman cultural tourism resources will help to form distinctive tourism products, open up a new tourism souvenir market and attract more tourists. It's wise to integrate the rich connotation of Shaman culture into tourism and make further rational development to show it to the public, so that more people can understand, love, inherit and protect Shaman culture. The rational development and utilization of Shaman cultural resources in Changbai Mountains not only enriches the diversification of tourism, but also encourages the local government and the public to protect and inherit traditional culture and advance the development of local tourism economy.

\section{PRESENT SituATION AND EXISTING PROBLEMS OF TOURIST SOUVENIRS IN CHANGBAI MOUNTAIN NATURE RESERVE}

\section{A. Development Status of Tourist Souvenirs in Changbai Mountain Nature Reserve}

1) Existing categories of tourist souvenirs: The rich tourism resources and cultural heritage of Changbai Mountain Nature Reserve can provide good help for the design of tourist souvenirs. At present, the types of tourist souvenirs in Changbai Mountain mainly include Changbai Mountain native products, cultural relics, arts and crafts and modern industrial products.

Changbai Mountain is rich in wildlife resources, such as pilose antler, ginseng, wild honey and so on and all of them have high medicinal value with exquisite packaging, suitable for presenting to parents and friends as gifts. Cultural relics and antiques in scenic spots usually have the characteristics of Shaman culture. Moreover, wood and mineral resources in Changbai Mountain Nature Reserve are very abundant. Wood 
carvings and stone carvings are high-grade tourist souvenirs. There are also paintings, silk products, key chains and other decorations in Changbaishan Tianchi style, wooden combs, cosmetic bags and other daily necessities, and plush toys with Tianchi Water Monster as the main image.

2) Market situation of tourist souvenirs: The major tourist attractions of Changbai Mountain have attracted many tourists at home and abroad. However, the market competitiveness of tourist souvenirs is not enough. In the tourist market of Changbai Mountain Nature Reserve, the development of tourist souvenirs is a relatively weak link. From the perspective of tourists' demand, tourists who buy souvenirs mainly include domestic tourists and Korean tourists. They usually buy middle and low-grade tourist goods, including Changbai Mountain specialty and some small handicraft products. From the supplier's point of view, besides the regular shops selling tourist souvenirs in the scenic area, there are also small businesses around, which are not large in scale, limited in variety and style, and obviously lack of characteristics. And there are many imitations, such as Korean crafts, Korean banknotes and Korean commemorative stamps, Russian metal crafts and so on. These products are almost all counterfeit products. Handicrafts with high commemorative significance and artistic collection value are well developed and have specific sales markets, such as expensive graphite, Korean pine, and jade and so on.

\section{B. Problems of Tourist Souvenirs in Changbai Mountain Nature Reserve}

1) Lack of special commemorative significance and cultural connotation: There are few special souvenirs in the scenic spot, and the commodities are not attractive. Many kinds of tourist souvenirs are featured by regionalism in Changbai Mountain Nature Reserve. At present, some Korean commodities and Russian handicrafts serve as the main souvenirs of Changbai Mountain. Although they are popular with tourists, they lack the characteristics of Changbai Mountain Nature Reserve. However, high-end crafts have a better development in Changbai Mountain tourist souvenirs. Generally speaking, most of the souvenirs in Changbai Mountain Nature Reserve lack cultural connotation and commemorative significance. For example, when domestic tourists visit Jingdezhen, they remember to buy porcelain there, and when they visit Yunnan, they will buy jade. But when they arrive at Changbai Mountain, they don't know what souvenirs they should buy, so most tourists only buy local specialties.

2) Poor product quality and low grade: Changbai Mountain vesuvianites are an important source of materials for crafts. However, many crafts are too simple, rough and unattractive. For some handicraft products with Shaman culture, the workmanship is often very rough. In general, the processing of products with local characteristics is still in the initial stage and the quality tends to be poor. These products are sold directly to tourists, leaving a bad impression on them and causing a negative impact to the local tourism industry.

3) Unreasonable price of souvenirs: The tourist souvenirs in Changbai Mountain Nature Reserve are insufficient in connotation and low in quality, but their prices are high, which makes potential buyers flinch. In addition, there are smaller souvenir dealers in Changbai Mountain Nature Reserve, and the competitiveness of high-grade souvenirs naturally declines. If the dealers just blindly pursue high-price of souvenirs, it will seriously affect the overall revenue of souvenir sales in Changbai Mountain. Another reason is that there are many imitations in Changbai Mountain Nature Reserve, and the prices of the same commodity sold by different stores are uneven, making tourists feel dissatisfied when they buy one commodity and verify the prices of the same good in another store, thus destroying the overall tourism image of Changbai Mountain.

4) Nonstandard market operation: With the development of the tourist souvenir market in Changbai Mountain Nature Reserve, the sales of souvenirs still have not formed a certain scale because there are no large and high-end tourist shopping centers. Without proper management, it is not easy to shape an effective market management system; without the guidance of professionals, it is not easy to establish self-discipline mechanism. At the same time, the operators of Changbai Mountain Nature Reserve mostly do business by small-sized booths and shops and individual workshops of small scale as well as weak intensity. In these small-scale business, the types of memorial cultivars can be controlled are less, and their themes are not prominent. Most of the souvenirs are Russian metal crafts, Korean crafts and commemorative stamps, which have nothing to do with the natural scenery and culture of Changbai Mountain. At present, people do not know the importance of the tourist souvenir market very well, and few measures have been taken in production, running and management. Therefore, the souvenir market in Changbai Mountain has been being in a low level of management for a long time.

\section{STUdy ON THE DEVElOPMENT STRATEGY OF TOURIST SOUVENIRS IN CHANGBAI MOUNTAIN NATURE RESERVE}

\section{A. Design Strategy of Tourist Souvenirs in Changbai Mountain Nature Reserve}

From the perspective of economics, the rise and development of any industry is closely related to the development and utilization of resources. Effective integration and development of folk tourism resources in Changbai Mountain Nature Reserve can not only accelerate local economic development, but also promote the formation of local tourism industrialization.

According to relevant surveys, the development rate of tourism and building facilities in the surrounding areas of Changbai Mountain has been high in recent years, while the development rate of tourist souvenirs and small and mediumsized cultural activities is relatively low, the lowest of which is 
tourist souvenirs. The tourism souvenirs of Changbai Mountain Nature Reserve have high potential economic value and large mining space. If it is rationally and effectively developed, the exploitation of the Changbai Mountain tourist souvenir market will present a new look and a qualitative leap.

It's necessary for Tourist souvenirs in Changbai Mountain Nature Reserve to set themes: first, the design of Changbai Mountain regional characteristics; second, the combination of Shaman culture and the theme of the times. Changbai Mountain tourism souvenir based on Shaman culture is the main direction of innovation at present. It will be better to apply clever language expression to modify the product shape, display the value of the product in an all-round way, and attract consumers' attention with cleverness. The natural materials in Changbai Mountain area should be excavated from materials and texture. Meanwhile, the main design can start with practicability, beauty, portability and commemoration.

\section{B. Specific Measures for Developing Tourist Souvenirs in Changbai Mountain Nature Reserve}

1) Making innovative improvements to souvenirs and adding cultural elements: In today's era of fierce market competition, tourism souvenirs with local characteristics and cultural connotations will assist them to last forever in this battlefield. Souvenirs sold by other scenic spots and can be accessed everywhere will not arouse tourists' desire to buy. The administrative departments of scenic spots should strive to appeal to the operators to sell goods that can reflect the characteristics of the scenic spots and limit the circulation of souvenirs without characteristics. Changbai Mountain is the birthplace of Manchu and the settlement of Korean nationality. So, the integration of Shaman culture and Korean folklore into the development and design of tourist souvenirs can not only reflect the characteristics of Changbai Mountain, but also enrich the types of souvenirs. In order to highlight the cultural connotation of tourist souvenirs, Shaman culture should be the theme of tourism souvenirs in Changbai Mountain Nature Reserve. In this theme, Shaman clothing, artworks, ornaments, altars and sacrifices are full of mysterious artistic hue, and they all symbolize the harmonious coexistence of man and nature, and the favorable climatic weathers. These cultural elements also have a far-reaching impact on the customs and culture of Northeast China.

2) Improving the quality of souvenirs: In order to improve the quality of tourist souvenirs, it's crucial to start from the aspects of production to strengthen the material, design as well as packaging, and empower the aesthetics and practicability of souvenirs, so as to improve the satisfaction of tourists in tourist destinations. There is no doubt that excellent workmanship increases the value of original souvenirs. Without exquisite craftsmanship and high-quality workmanship, even with the best features, it will not increase the attention of consumers. Changbai Mountain is rich in medicinal resources. Local specialties are souvenirs that tourists like to buy for a long time, such as agaric, velvet antler and so on. When processing and packing medicinal materials, delicate packing boxes can be used. The design on the boxes is helpful for embodying the characteristics of Changbai Mountain, which will increase the tourists' preference for local specialties. For medium and low-grade tourist souvenirs, the raw materials that can be collected in Changbai Mountain are generally selected, and the unique characteristics of Changbai Mountain can be integrated to reduce the cost by unified processing and unified sales. For high-end tourist souvenirs, it's wise to choose precious resources with Changbai Mountain characteristics, such as vesuvianite, carbonized wood, redwood, etc., to make exquisite crafts for publicity and promotion to the market.

3) Setting reasonable prices: The management departments and tourism enterprises of Changbai Mountain Nature Reserve should first consider the purchasing power of most tourists, strictly control the prices of commodities and unify the prices of the same commodities. This will not only increase the satisfaction of tourists to the tourist destination, but also boost the trust of tourists to local businessmen. For foreign tourists, domestic tourists, high-consumption tourists and low-consumption tourists, there are always different needs for souvenirs. In order to expand the souvenir market and enhance competitiveness, different price levels of souvenirs should be developed according to the needs of diverse tourist groups.

4) Improving management system and strengthening cooperation with universities: It's pivotal for Changbai Mountain scenic spot to improve its management system, strengthen cooperation with universities and promote the effective development of tourist souvenirs. First, a production base for tourist souvenirs should be established. By contacting the existing operators and manufacturers, building the production base of tourist souvenirs can not only drive the production of surrounding township enterprises, but also promote the economic development of the whole Changbai Mountain. Second, special research institutions for tourism souvenir development should be set up. Due to the lack of professional design and development personnel, Changbai Mountain tourism souvenirs are just developed by experience, so that it is difficult to form a system. Therefore, the relevant party shall encourage universities or research institutes to compete in the design of tourist souvenirs in Changbai Mountain. Beyond guiding the development of tourist souvenirs scientifically, this step will help to improve the quality of souvenirs, increase their scientific and technological content and reduce the generation of imitations, finally creating a unique and independent souvenir brand in Changbai Mountain.

\section{CONCLUSION}

For most of us, tourist souvenirs carry the good memories of every trip. Therefore, the most important point of tourist souvenirs is to be embellished by local characteristics. So, it's necessary to do in-depth tapping of customs and culture of the scenic spots and then, design and produce tourist souvenirs of 
peculiar fabrication and high taste combining with strong traditional culture, advanced science and technology and local material resources. The opening up of tourist souvenirs is the core and source of traditional culture with strong vitality. For the scenic spot, it's important to fully tap the characteristic souvenir resources to enrich the tourist souvenir market. By this way, the characteristics of Changbai Mountains can be displayed to the utmost to make its tourism image set sights on the world level.

\section{REFERENCES}

[1] Liu Mingju, Sheng Yajun. Investigation and Research on the Development of Tourist Souvenirs in Jilin Province [J]. Journal of Green Science and Technology, 2017 (20): 223-225. (in Chinese)

[2] Liu Mingju, Zhao Liguang, Jingang. Problems and Development Strategies of Tourist Souvenirs in Jilin Province [J]. Tourism Overview(second half month), 2017(10):138-139. (in Chinese)

[3] Liu Mingju, Zhao Liguang and Zhao Shuwei. Research on the Development of Special Tourism Souvenirs in Jilin Province under New Normal Conditions [J]. Tourism Overview(second half month). 2016(03):135-136. (in Chinese)

[4] Liu Mingju, Yuan Fang. Some Thoughts on the Study of Tourism Resources [J].Taxation and Economy, 2016 (1) (in Chinese)

[5] Liu Mingju, Liu Mingli, Yu Yang. Study on the Countermeasures for the Development of Tourist Souvenirs in Jilin Province [J]. Journal of Green Science and Technology, 2015(08): 344-345+351. (in Chinese)

[6] Liu Lijun. On the Development of Tourist Souvenirs [J]. Business Economy. 2009 (7). (in Chinese)

[7] Shuai Ligong. Design of Tourist Souvenirs [M]. Beijing: Higher Education Press. 2007. (in Chinese) 